\title{
Foraging range and habitat associations of non-breeding Tristan albatrosses: overlap with fisheries and implications for conservation
}

\author{
Timothy A. Reid ${ }^{1}$, Ross M. Wanless ${ }^{1,2, *}$, Geoff M. Hilton ${ }^{3,5}$, Richard A. Phillips ${ }^{4}$, \\ Peter G. Ryan ${ }^{1}$ \\ ${ }^{1}$ Percy FitzPatrick Institute, DST/NRF Centre of Excellence, University of Cape Town, Rondebosch 7701, South Africa \\ ${ }^{2}$ Seabird Division, BirdLife South Africa, PO Box 7119, Roggebaai, 8012, South Africa \\ ${ }^{3}$ Royal Society for the Protection of Birds, The Lodge, Sandy, Bedfordshire SG19 2DL, UK \\ ${ }^{4}$ British Antarctic Survey, Natural Environment Research Council, High Cross, Madingley Road, Cambridge CB3 0ET, UK \\ ${ }^{5}$ Present address: Wildfowl and Wetlands Trust, Slimbridge, Gloucestershire GL2 7BT, UK
}

\begin{abstract}
The Tristan albatross Diomedea dabbenena is Critically Endangered: > $99 \%$ of adults breed at Gough Island, central South Atlantic Ocean, where chicks are threatened by introduced predators. At sea they mostly remain within the South Atlantic Ocean, where they are threatened by incidental capture in longline fisheries. Conservation measures to reduce seabird mortality in pelagic longline fisheries are confined largely to fishing effort south of $25^{\circ} \mathrm{S}$. This covers the core range of breeding Tristan albatrosses, but the distribution of non-breeding adults and immature birds is unknown. We tracked 14 non-breeding adult Tristan albatrosses from Gough Island for up to $3 \mathrm{yr}$, from 2004 to 2006, using geolocating loggers. All birds remained in the South Atlantic or southern Indian Oceans, and showed distributions centred on the Sub-Tropical Convergence. They used the SW Atlantic during the austral summer and the SE Atlantic and Indian Oceans as far east as Australia during the austral winter. Foraging effort was concentrated in areas of upwelling and increased productivity. The distribution of the tracked birds overlapped with a range of pelagic longline fisheries, especially off southern Africa. Of particular concern was that 2 birds spent several months off the coast of Namibia and in adjacent high seas north of $25^{\circ} \mathrm{S}$, where there are currently no regulations to prevent seabird bycatch during pelagic longline fishing operations.
\end{abstract}

KEY WORDS: Atlantic Ocean · Indian Ocean · Longline • Bycatch • Diomedea dabbenena • Namibia Resale or republication not permitted without written consent of the publisher

\section{INTRODUCTION}

Of all the groups of birds in the world, seabirds are the most threatened (Croxall et al. 2012). Albatrosses are particularly at risk, with 17 of the 22 species listed as threatened by the International Union for the Conservation of Nature (IUCN) (BirdLife International 2012). Seabirds face a range of threats, including fisheries mortality at sea, depletion of prey by fisheries, habitat destruction (either at sea or on land) and predation by introduced mammals at breeding islands (Moors \& Atkinson 1984, Tuck et al. 2003, Cuthbert et al. 2005, Wanless et al. 2009, Žydelis et al. 2009, Finkelstein et al. 2010). Marine threats are particularly difficult to study, given the limited monitoring of many fishing fleets and the resultant paucity 
of reliable data on bird bycatch. In addition, many species of seabirds range over vast areas and are thus likely to encounter multiple threats at sea in a variety of management jurisdictions (both national Exclusive Economic Zones [EEZs] and high seas areas) and to interact with fleets that vary widely in terms of compliance with conservation measures where these are in place.

The Tristan albatross Diomedea dabbenena breeds almost exclusively on Gough Island in the central South Atlantic Ocean. It is classified as Critically Endangered by the IUCN because of population declines caused by mortality on longlines and predation of chicks by introduced mice Mus musculus (Wanless et al. 2007, 2009, BirdLife International 2012). The population is estimated to be decreasing by almost $3 \% \mathrm{yr}^{-1}$, with annual mortality from longline fishing estimated to be around 250 individuals (Wanless et al. 2009). Tristan albatrosses have been killed by pelagic longline fisheries off Brazil (Olmos 1997, Cuthbert et al. 2005) and southern Africa (Petersen et al. 2009). A recent assessment conducted under the auspices of the International Commission for the Conservation of Atlantic Tunas (ICCAT) concluded that the Tristan albatross was one of the species most at risk from longline fishing within the ICCAT area of jurisdiction (Tuck et al. 2011). A qualitative risk assessment for seabirds in the area managed by the Indian Ocean Tuna Commission (IOTC) came to a similar conclusion in terms of the threat to Tristan albatrosses from fishing in the Indian Ocean (Baker \& Wanless 2010).

Identifying the main foraging areas of the Tristan albatross is complicated because at sea they are difficult to distinguish from other great albatrosses Diomedea spp.; indeed, separation from wandering albatross $D$. exulans requires measurements of birds in the hand (Cuthbert et al. 2003, Ryan 2007). The only published assessment of their foraging range is derived from tracking data for breeding birds in 2000. In that study, birds remained predominantly in the central South Atlantic, though some travelled as far as South America and South Africa (Cuthbert et al. 2005). However, foraging ranges of adult albatrosses can be substantially larger in the non-breeding period, when they are not constrained to return to a central location to incubate or provision their chick (BirdLife International 2004, Phillips et al. 2005, Weimerskirch et al. 2012). Given the ongoing threat to this Critically Endangered species, it is imperative to better understand their movement patterns and habitat use during all life-cycle stages. Here we present new information on the distribution of non- breeding Tristan albatrosses in relation to longline fishing effort and environmental characteristics.

\section{MATERIALS AND METHODS}

Tristan albatrosses Diomedea dabbenena breed biennially, and are currently restricted to breeding at 2 sites in the South Atlantic Ocean. At Gough Island $\left(40^{\circ} 19^{\prime} \mathrm{S}, 9^{\circ} 56^{\prime} \mathrm{W}\right)$ around 1400 pairs breed annually. At Inaccessible Island $\left(37^{\circ} 18^{\prime} \mathrm{S}, 12^{\circ} 40^{\prime} \mathrm{W}\right)$, a tiny number of pairs breed and, on average, $<1$ chick fledges each year from Inaccessible Island (Wanless et al. 2009).

\section{Position-tagging devices}

Global location sensor (GLS) loggers (British Antarctic Survey, Cambridge, UK), often referred to as geolocators, were attached to leg bands on 43 Tristan albatrosses breeding on Gough Island. Devices were ground-truthed for $2 \mathrm{wk}$ at the colony, and then fitted to adults feeding large chicks in August and September 2004. The devices weighed $9 \mathrm{~g}$, equivalent to $<0.2 \%$ of the weight of a mature Tristan albatross $(>7 \mathrm{~kg})$, well below the load that might be expected to affect foraging behaviour (Phillips et al. 2003, Passos et al. 2010).

GLS loggers measured light intensity every minute and recorded the maximum in each 10 min period. Downloaded light data were processed to estimate the time of sunrise, sunset and, hence, local midday relative to GMT/UTC, and daylength. From these parameters, it is possible to estimate latitude and longitude. However, there are inaccuracies in positions derived in this way due to factors such as cloud cover, shading of the light sensor by feathers, or rapid movements by flying birds. Positions are accurate to roughly $200 \mathrm{~km}$, except around the equinoxes when latitudinal errors increase (Phillips et al. 2004). An iterative speed filter was used to identify unlikely locations (McConnell et al. 1992). For this, an average was taken over 5 positions, and those positions that required a maximum average speed of $>80 \mathrm{~km}$ $\mathrm{h}^{-1}$ (Weimerskirch et al. 1993) were filtered using the tripEstimation package (Version 0.0-37). To estimate the areas used most frequently, we applied kernel smoothing to the filtered positions using the ks package (Version 1.8.12) in R. Most frequently used areas were presented as percentage volume contours, such that $50 \%$ contours show the most dense $50 \%$ of all locations (Tancell et al. 2013). All statistical analyses 
were conducted in R, Version 2.15.0 (R Development Core Team 2012).

Devices deployed in late 2004 were retrieved during the 2006 breeding season, and, hence, the study included the end of the 2004 breeding period, the entire 2005 sabbatical year and the start of the 2006 breeding period. Based on the GLS positional data, none of the study birds appeared to breed during 2005 (there was no researcher on the island that breeding season to confirm their absence from the breeding colony). Breeding/non-breeding activity was classed based on known breeding history and movement patterns (e.g. birds regularly attending the island were assumed to be breeding). Only data from the non-breeding period (including both failed and successful breeders at the previous attempt) are presented here. Data for breeding birds suggested the use of similar areas to those described in Cuthbert et al. (2005).

\section{Longline fishing effort distribution}

Longline fishing effort data are presented here at the finest spatial resolution available. Quarterly data at a $5^{\circ} \times 5^{\circ}$ resolution over $5 \mathrm{yr}$ (2001 to 2006) were obtained from the ICCAT for the Atlantic Ocean (www.iccat.es/en/accesingdb.htm), and monthly data for the Indian Ocean were obtained from the IOTC (www.iotc.org/English/data/databases.php\#dl).

\section{Modelling effects of environmental conditions}

To test how non-breeding Tristan albatrosses were distributed in relation to environmental conditions, we followed the approach of Aarts et al. (2008) and Wakefield et al. (2011). Tracking data are presence only, so we created pseudo-absences in order to examine habitat preferences using logistic regressions, where records of birds were given a value of 1 , and pseudo-absences, a value of 0 . Pseudo-absence data are derived from positions chosen from areas available to the population (Aarts et al. 2008). Choice of pseudoabsence position is important, and overcomplicating models of possible areas can lead to poor prediction (Wisz \& Guisan 2009). In the present study, possible pseudo-absences were confined to areas to which the study birds could realistically move. Because nonbreeders are not constrained to return to their nests, this was considered to be the maximum extent of the area used during this study, i.e. from 15 to $60^{\circ} \mathrm{S}$ in the Atlantic Ocean and 30 to $60^{\circ} \mathrm{S}$ in the Indian Ocean; no birds visited the Pacific Ocean. During summer (November to April), all birds remained within the Atlantic Ocean. Thus, pseudo-absences were randomly chosen from within these spatio-temporal constraints. We generated 100 points bird ${ }^{-1} \mathrm{mo}^{-1}$ throughout the year, giving 4085 presences and 15535 absences.

Monthly sea-surface temperature (SST) and Aqua Modis chlorophyll $a(\mathrm{chl} a)$ in milligrams per cubic metre at $4 \mathrm{~km}$ resolution were downloaded from SeaWifs via http://oceancolor.gsfc.nasa.gov/, and monthly mean sea-level anomaly (SLA) data, from Aviso at www.aviso.oceanobs.com at a $0.333^{\circ} \times$ $0.333^{\circ}$ grid scale. Variables chosen were ones that have previously been demonstrated to correlate with distributions of other seabird species (e.g. Phillips et al. 2006, Wakefield et al. 2011). We modelled the tracking data using a generalised additive mixed model (GAMM) using the mgcv (Version 1.7-13) package in R. Individual bird identity was treated as a random effect. Fixed effects were latitude and longitude as interacting terms, SST, chl $a$, water depth and mean SLA). We took a Bayesian view that all variables chosen for fixed effects were components of the world, and therefore should be presented, rather than using any form of model selection to narrow the suite of variables (Bolker 2008). This was considered appropriate as the model was descriptive rather than predictive.

\section{RESULTS}

Of the 43 GLS loggers deployed, 35 (81\%) were retrieved, but data were obtained from only 15 devices (the others failed to download data). Fourteen contained data on non-breeding movements of Tristan albatrosses (13 post-breeding and 1 late failure), while 1 only contained data for the breeding period. The core areas (i.e. $50 \%$ kernels) of most birds were between $\sim 25$ and $\sim 45^{\circ} \mathrm{S}$, year-round. Most positions were around the Sub-Tropical Convergence and farther north, typically in waters of 10 to $20^{\circ} \mathrm{C}$ (range: 0 to $24^{\circ} \mathrm{C}$; Fig. 1). Distributions were largely centred in oceanic waters (>3000 m deep).

Non-breeding adult Tristan albatrosses ranged across the Atlantic and Indian Oceans, encompassing half the globe from the east coast of South America $\left(50^{\circ} \mathrm{W}\right)$ to the Great Australian Bight $\left(130^{\circ} \mathrm{E}\right)$. However, most locations ( $86 \%$ ) were in the Atlantic Ocean (west of $20^{\circ} \mathrm{E}$ ), and only 2 birds ranged well into the Indian Ocean. Non-breeding adults occurred predominantly in the SW Atlantic from January to March (Fig. 2a-c), shifting to the SE 


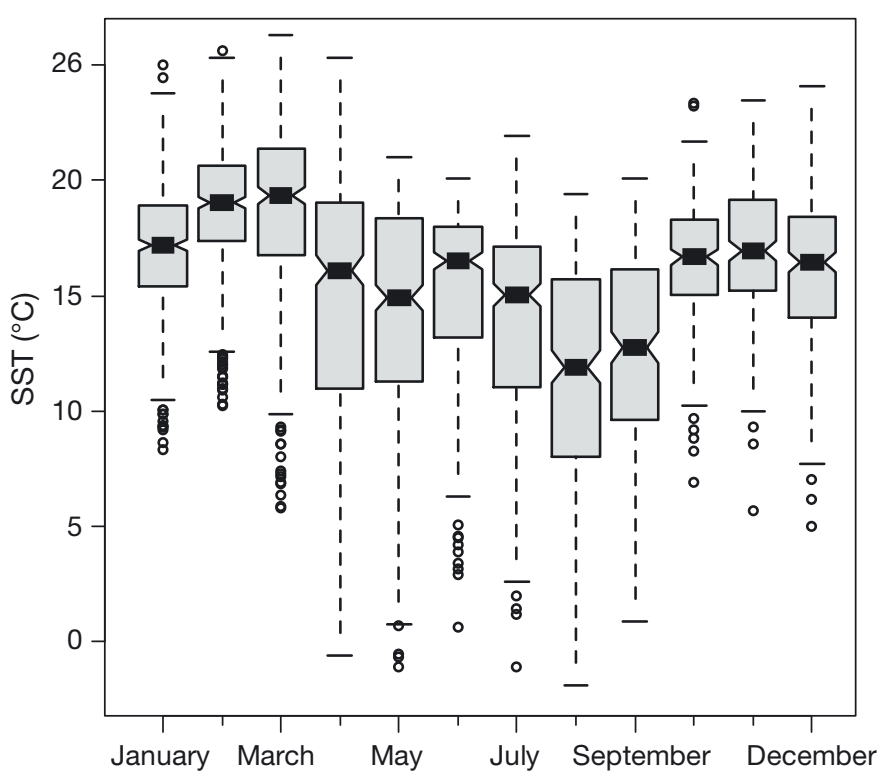

Fig. 1. Variation in sea-surface temperature (SST) encountered by non-breeding Tristan albatrosses Diomedea dabbenena by month during 2005 . The box shows the 25 and $75 \%$ quartiles (the inner quartiles), the notch occurs at $\pm 1.58 \times$ $\mathrm{IQR} / \mathrm{sqrt}(\mathrm{n})$, where IQR is the inner quartile range and $\mathrm{n}$ is the number of observations in that month. Whiskers are drawn at 1.5 $\times$ IQR beyond the inner quartiles
Tristan albatross distributions overlapped with high levels of longline fishing effort from April to August off South Africa, where birds spent most of their time in areas of eddies and mixing associated with the Agulhas Current (Figs. 2d-f \& 3b-d, Table 1). The intensity of fishing effort in the areas used by non-breeding Tristan albatross during this study was greater in the Indian Ocean than in the Atlantic Ocean, with a maximum of 2.76 million hooks set during a month in a single $5^{\circ} \times 5^{\circ}$ block in the Indian Ocean, compared with an average of 1.1 million hooks set over 3 mo during 2001 to 2006 in the block with the greatest effort in the Atlantic Ocean. Most overlap between adult Tristan albatrosses and longline fishing effort occurred during winter (Quarters 2 and 3; Table 1); during Quarter 3, all tracked birds visited a $5^{\circ} \times 5^{\circ}$ square in which fishing effort had averaged >500 000 hooks $\mathrm{yr}^{-1}$ from 2001 to 2006 .

The GAMMs comparing presences and pseudo-absences suggested that Tristan albatrosses were significantly more likely to occur in the SW or SE Atlantic Ocean or off SW Australia (estimated degrees of freedom, edf $=27.0 ; F=58.7 ; \mathrm{p}<0.01$ ). They preferred waters $\sim 3000$ to $5000 \mathrm{~m}$ deep, with surface temperatures of 15 to $20^{\circ} \mathrm{C}$ (Fig. $4 \mathrm{a}$; edf $=5.9 ; F=15.5 ; \mathrm{p}<$ 0.01) and enhanced chl a concentrations (Fig. 4b; edf $=1.0 ; F=6.0 ; \mathrm{p}=0.01$ ), and avoided shelf waters
Atlantic from March to May (Fig. 2c-e). During austral winter (May to September), most time was spent in the SE Atlantic off South Africa (Fig. 2e-i) and eastward into the Indian Ocean to $\sim 40^{\circ} \mathrm{E}$ (Fig. $3 \mathrm{~b}-\mathrm{f}$ ). Two birds moved to Namibia in lateMarch and remained there until June, with 1 of these returning during August (Fig. 2c-f, h). In April, 2 individuals (14\% of tracked birds) began moving to SW Australia, arriving in June. They returned westward, against the prevailing winds, in September (Fig. 3), resulting in their winter foraging ranges being predominantly in the Indian Ocean. In spring (October), prior to the onset of breeding, adults started to return to the SW Atlantic (Fig. 2j), and all birds were in this area in November (Fig. 2k). By December, immediately before breeding commenced, all tracked birds were concentrated in the central South Atlantic around Gough Island (Fig. 2k).
Table 1. Diomedea dabbenena. Overlap of tracked non-breeding Tristan albatrosses and longline fishing in the South Atlantic and Indian Oceans. Values in parentheses beside quarters show no. of tracked birds. ICCAT: International Commission for the Conservation of Atlantic Tuna; IOTC: Indian Ocean Tuna Commission. No. of tracked birds: no. of individuals in that year quarter; blocks with fishing effort: no. of $5^{\circ} \times 5^{\circ}$ squares which had some fishing effort during the quarter in 2001 to 2006 ; blocks with high fishing effort: no. of $5^{\circ} \times 5^{\circ}$ squares where an annual average of $>500000$ hooks was set between 2001 and 2006; no. of birds visiting a block with high effort: no. of individual Tristan albatrosses that visited a square where $>500000$ hooks were set each year; tracked birds visiting a square with high effort: percentage of total tracked individuals that visited a square with $>500000$ hooks yr ${ }^{-1}$ (note that in Quarter 3 two birds visited squares with $>500000$ hooks set in both the Atlantic and Indian Oceans)

\begin{tabular}{|lcccc|}
\hline & \multicolumn{4}{c|}{ Quarter } \\
\cline { 2 - 5 } & $1(14)$ & $2(13)$ & $3(11)$ & $4(7)$ \\
\hline ICCAT & 100 & 100 & 100 & 100 \\
Blocks with fishing effort & 3 & 2 & 1 & 2 \\
Blocks with high fishing effort & 0 & 8 & 4 & 0 \\
No. of birds visiting a block with high effort & & & & \\
IOTC & 141 & 141 & 148 & 148 \\
Blocks with fishing effort & 23 & 23 & 49 & 46 \\
Blocks with high fishing effort & 0 & 0 & 9 & 1 \\
No. of birds visiting a block with high effort & 0 & 62 & 100 & 14 \\
Tracked birds visiting block with high effort (\%) & 0 & & & \\
\hline
\end{tabular}




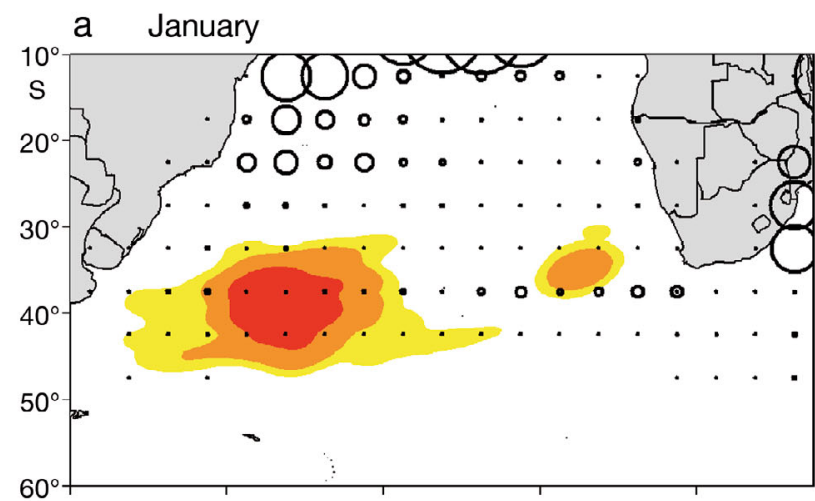

b February
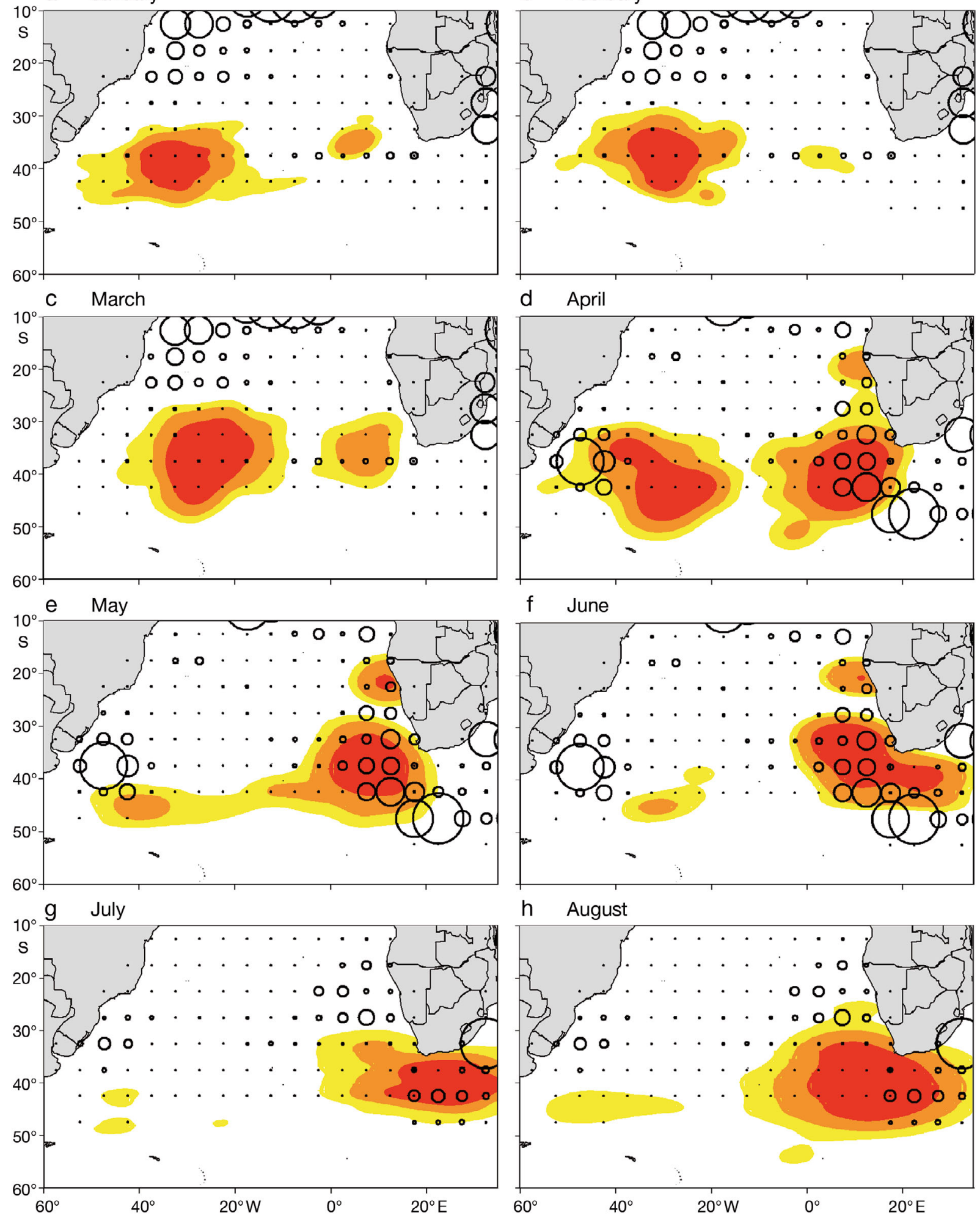

\section{h August}

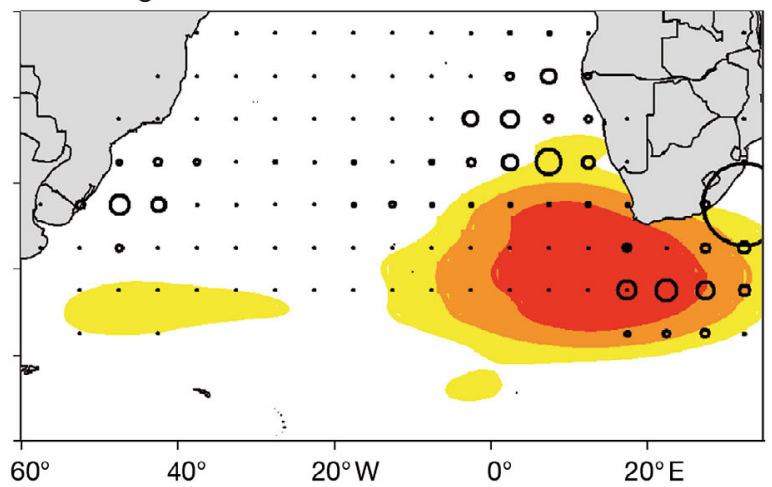

Fig. 2. Diomedea dabbenena. (a to 1) Kernel plots (50, 75 and 90\% isopleths) of non-breeding adult Tristan albatross distributions within the South Atlantic Ocean in 2005, overlaid on fishing effort by pelagic longliners targeting tuna and other billfishes (red: $50 \%$; orange: $75 \%$; yellow: $90 \%$ ). Fishing effort is mean quarterly number of hooks set within $5^{\circ} \times 5^{\circ}$ blocks for the period of 2001 to 2006, with circles proportional to the number of hooks set (maximum number of hooks set in Quarter 1: 1.0 million, Quarter 2: 1.0 million, Quarter 3: 0.6 million, Quarter 4: 1.1 million)

(Fig. 2 continued on next page) 

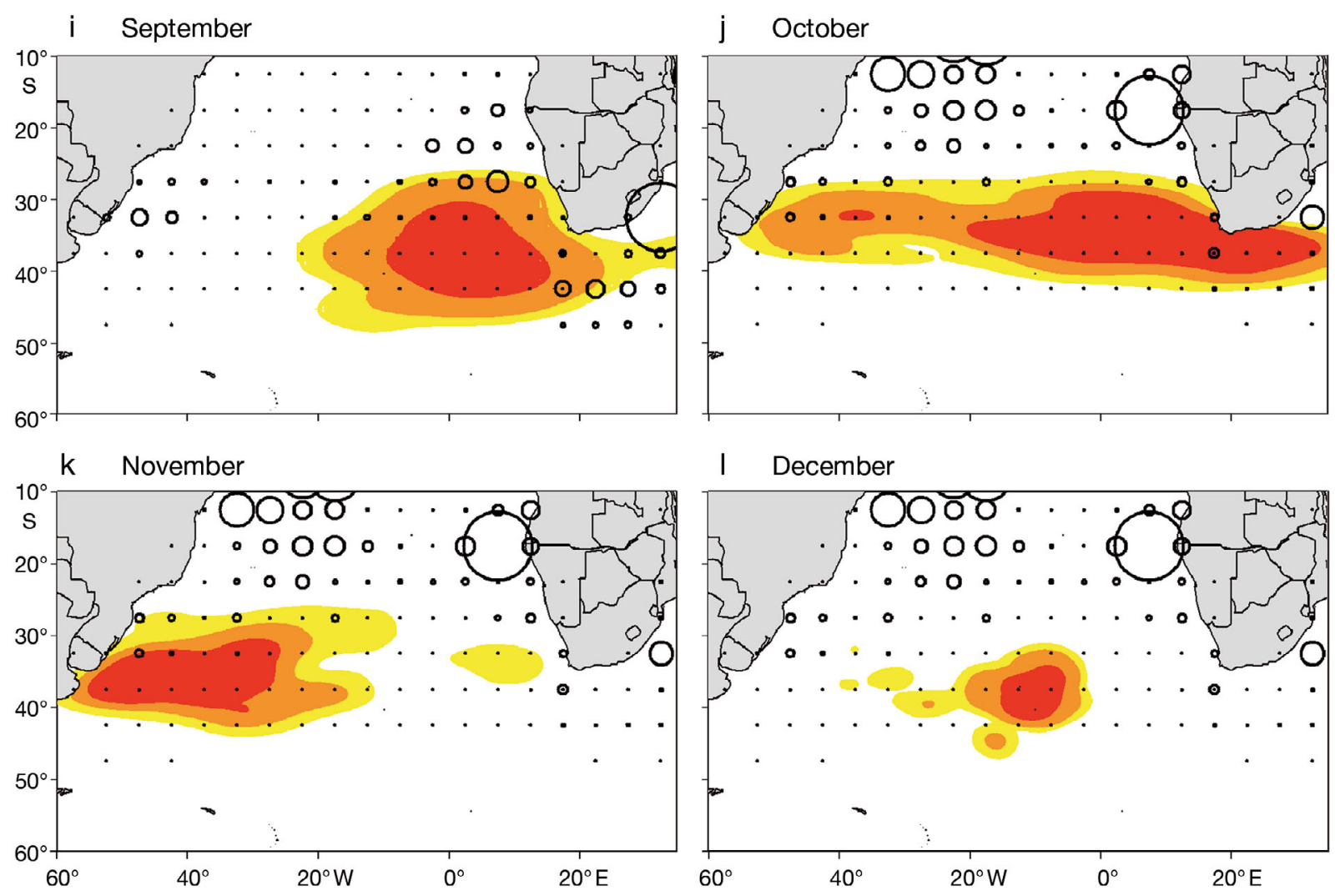

Fig. 2. (continued)

(Fig. $4 \mathrm{c} ;$ edf $=4.1 ; F=4.3 ; \mathrm{p}<0.01$ ). Mean SLAs had less influence on their distribution, except for a weak tendency of Tristan albatrosses to favour areas with reduced mean SLA values (Fig. $4 \mathrm{~d}$; edf $=1.0 ; F=4.3$; $\mathrm{p}=0.04)$. However, when mean SLAs were examined in isolation, tracked Tristan albatrosses were least likely to visit areas where there was no mean SLA. The overall model had an adjusted $\mathrm{r}^{2}$ of 0.26 .

\section{DISCUSSION}

\section{Overlap with breeding birds and other species}

The ranges of non-breeding Tristan albatrosses were substantially greater than those of breeding adults (Cuthbert et al. 2005; Fig. 5), which are required to return regularly to Gough Island to incubate or to provision their chick. Breeding birds remain predominantly in waters of the central South Atlantic Ocean around Tristan da Cunha and Gough Islands, with east-west movements largely confined to the area from $15^{\circ} \mathrm{E}$ to $50^{\circ} \mathrm{W}$ (Cuthbert et al. 2005). Although non-breeders spent most of their time in the South Atlantic Ocean, there was little overlap in their distribution with the core areas used by breeders (in the central Atlantic), suggesting spatial niche partitioning between adults of different status. Generally, Tristan albatrosses occur in subtropical waters or around the Sub-Tropical Convergence, rather than in more southerly waters. While there was some overlap with wandering albatrosses from their more southerly colonies on South Georgia, the Prince Edward Islands, Iles Crozet and Kerguelen (Prince et al. 1992, Weimerskirch et al. 1993, Nel et al. 2002, BirdLife International 2004), Tristan albatrosses foraged predominantly to the north of adult wandering albatrosses and were more likely to overlap with female and non-breeding wandering albatrosses than with breeding males.

\section{Non-breeding movements}

Non-breeding Tristan albatrosses move extensively throughout 2 southern ocean basins. The areas they utilise off both South America and southern Africa are associated with eddies and mixing zones (Figs. 6 \& 7), which are typically highly productive (Wainer et al. 2000) There were clear seasonal pat- 


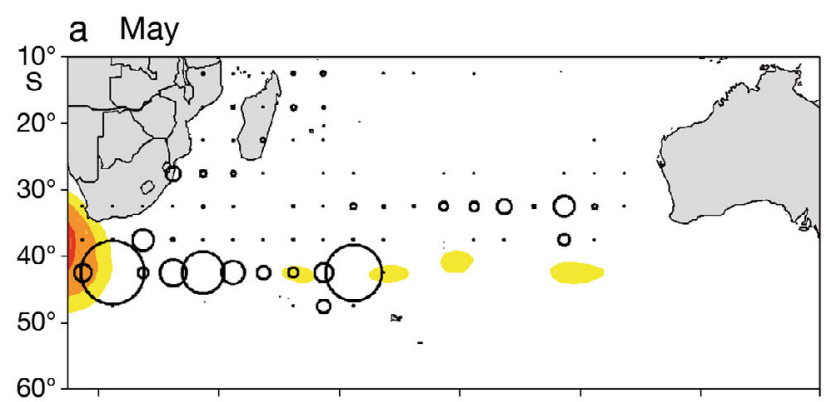

b June
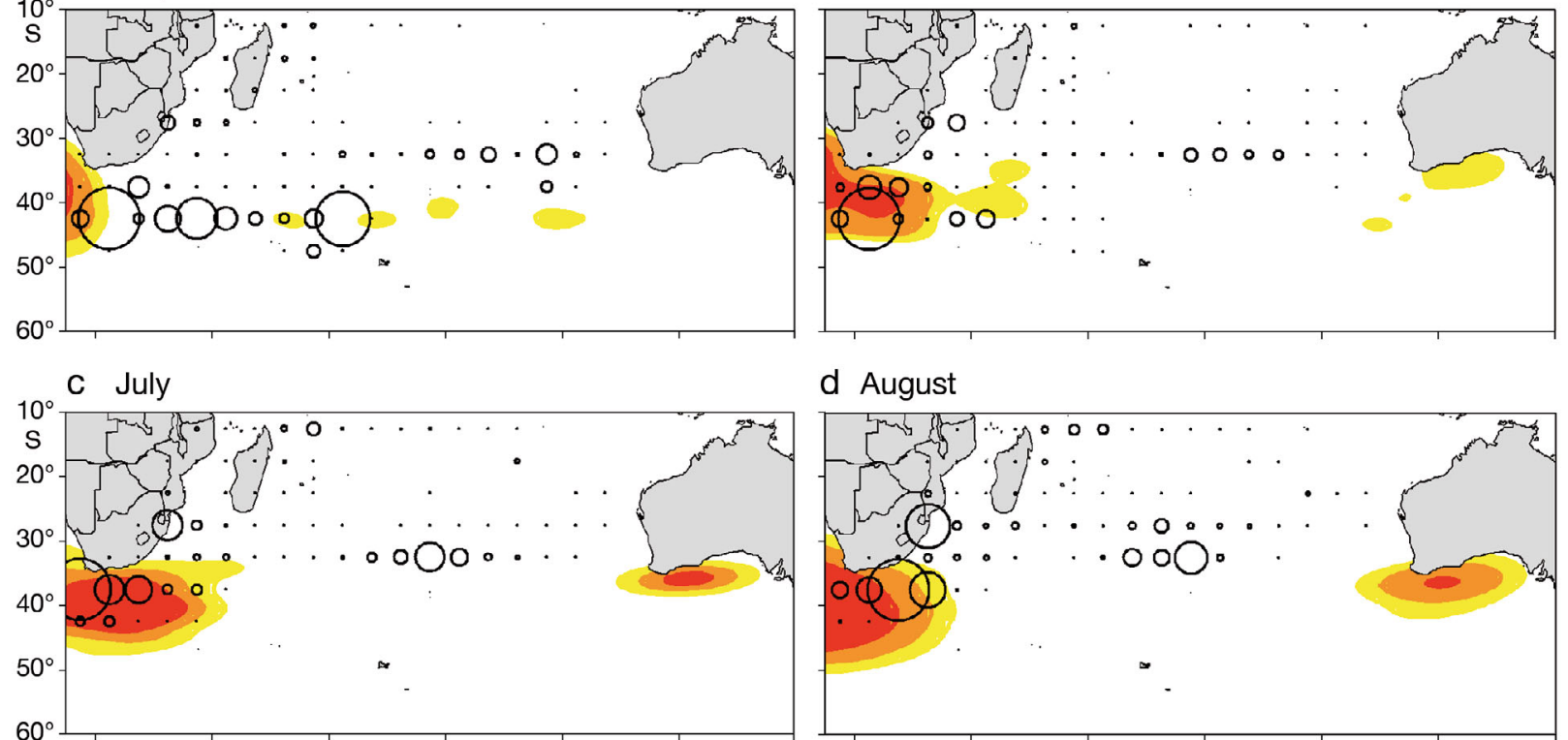

d August
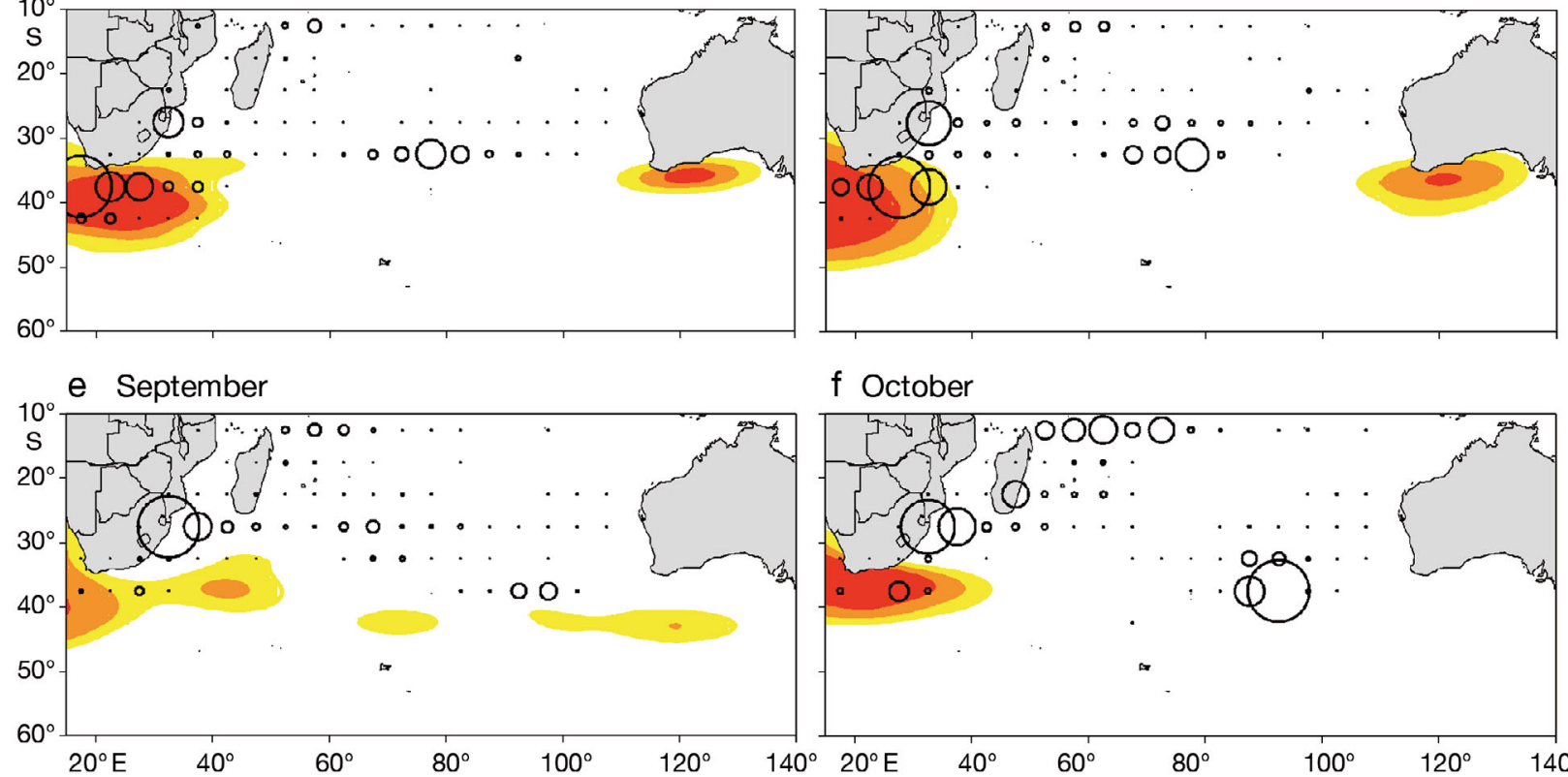

f October

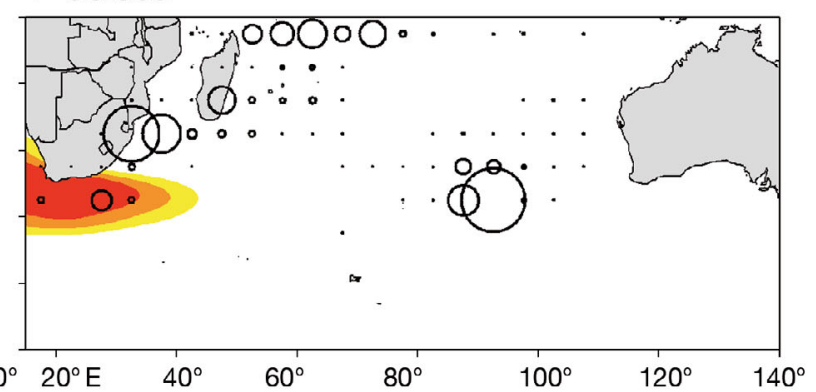

Fig. 3. Diomedea dabbenena. (a to f) Kernel plots (50, 75 and $90 \%$ isopleths) of non-breeding adult Tristan albatross distributions within the Indian Ocean in 2005 (red: 50\%; orange: $75 \%$; yellow: $90 \%$ ), overlaid on fishing effort by pelagic longliners targeting tuna and other billfishes. Fishing effort is total hooks set monthly within $5^{\circ} \times 5^{\circ}$ blocks (maximum number of hooks set in a block during a month in observation period: 2.8 million), with circles proportional to the number of hooks set

terns to their movements, with all tracked birds concentrating in the SW Atlantic during austral summer, but travelling eastward and dispersing more widely during austral winter, mostly to the SE Atlantic and SW Indian Ocean off South Africa. However, 2 birds moved to waters off northern Namibia and 2 to southern Australia. It is important to note that, although we present results from 2005 only, the limited tracking data available for non-breeding birds in 2004 and 2006 showed a broadly similar pattern.

\section{Overlap with oceanography}

Our analyses indicate that although Tristan albatrosses tend to concentrate in productive areas at frontal zones and around eddies, their overall distri- bution includes waters that vary widely in terms of primary productivity. There are several possible explanations. Tristan albatrosses may be able to get sufficient food to meet their energetic requirements, while avoiding competition, by remaining in slightly lower quality areas. Alternatively, there may be a mismatch between chlorophyll a measured by satellite imagery (which is at the lowest trophic level) and the distributions of higher trophic-level organisms that Tristan albatrosses are likely to target (fish and squid; Imber 1992). In addition, the GLS data used in the modelling are inherently imprecise, which means that habitat can only be described at broad spatial scales. In order to investigate habitat preferences more closely, more accurate tracking data from GPS loggers or satellite-tags would be required. 

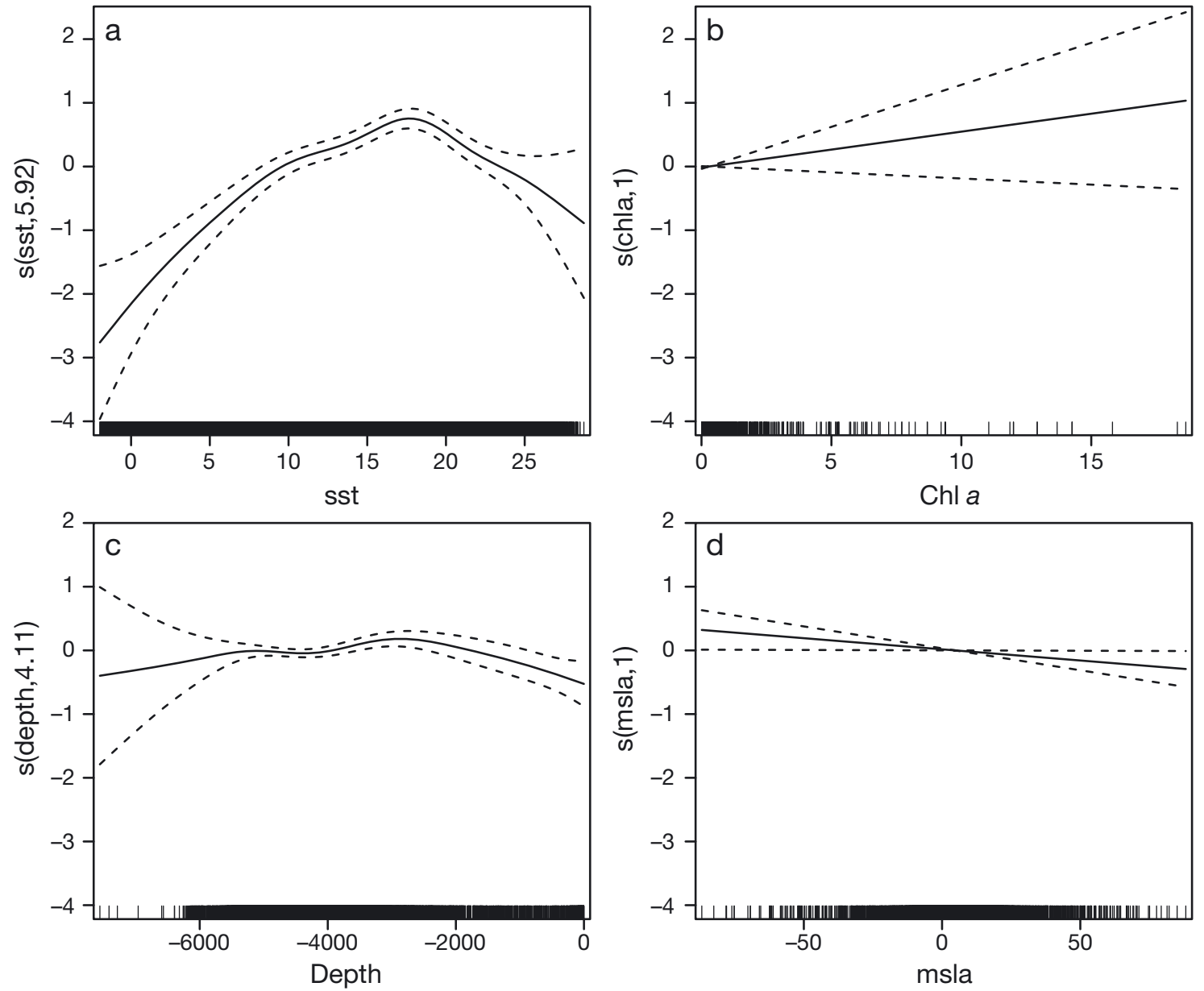

Fig. 4. Diomedea dabbenena. Plots of some fixed effects of the model of non-breeding Tristan albatrosses during 2005. The $y$-axes show the partial residuals once the effect of other variables has been removed. Solid lines are means and dashed lines are estimated $95 \% \mathrm{CIs}_{\text {; ' }} \mathrm{s}$ ' is a smoothing term, with values in parentheses the effective degrees of freedom. (a) Sea-surface temperature (SST, $\left.{ }^{\circ} \mathrm{C}\right),(\mathrm{b})$ chlorophyll a $\left(\mathrm{chl} a, \mathrm{mg} \mathrm{m}^{-3}\right)$, (c) depth (m), (d) mean sea-level anomaly (SLA, cm)

During austral summer, non-breeding Tristan albatrosses occurred predominantly in the SW Atlantic Ocean between 30 and $45^{\circ} \mathrm{S}$ and 0 and $50^{\circ} \mathrm{W}$. This

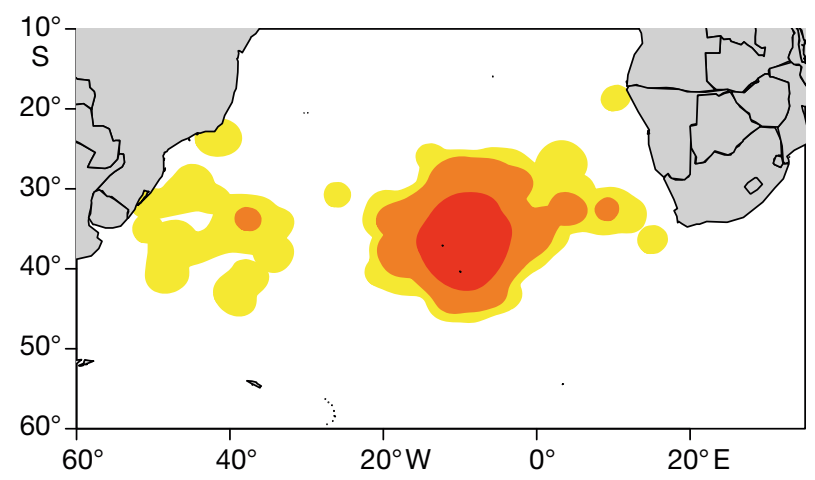

Fig. 5. Diomedea dabbenena. Kernel plots (50, 75 and $90 \%$ isopleths) of breeding adult Tristan albatrosses tracked from 2004 to 2006 (red: $50 \%$; orange: $75 \%$; yellow: $90 \%$ ) area is influenced by a number of strong oceanographic features, including the Sub-Tropical Convergence between the Brazil/Malvinas (Falklands) Confluence (Fig. 6), that result in eddies and vertical mixing that enhance local production. This area has consistently high productivity in summer and low productivity in winter (Wainer et al. 2000), supporting the conclusion that its importance to seabirds is likely to vary seasonally. It is a key foraging area for other marine predators in summer, including black-browed albatrosses Thalassarche melanophris (Wakefield et al. 2011) and white-chinned petrels Procellaria aequinoctialis (Phillips et al. 2006) from South Georgia, southern elephant seals Mirounga leonina from Argentina (Campagna et al. 2006), and migrant Cory's Calonectris diomedea (Dias et al. 2011), sooty Puffinus griseus (Hedd et al. 2012) and Manx P. puffinus (Guilford et al. 2009) shearwaters. 


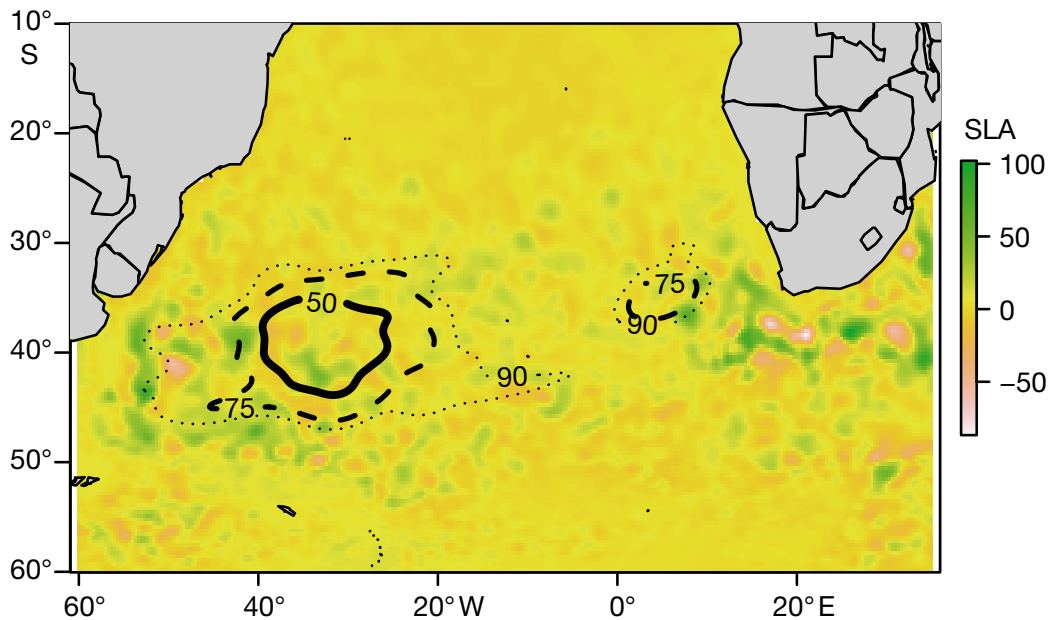

Fig. 6. Diomedea dabbenena. Kernel plots of non-breeding adult Tristan albatrosses during January 2005 overlaid on mean sea-level anomaly (SLA, cm) in Atlantic and SW Indian Oceans (solid line: 50\%; dashed line: 75\%; dotted line: $90 \%$ )



Fig. 7. Diomedea dabbenena. Kernel plots of non-breeding Tristan albatrosses in the South Atlantic Ocean during June 2005 overlaid on mean sea-level anomaly (SLA, $\mathrm{cm}$ ) in Atlantic and SW Indian Oceans (solid line: 50\%; dashed line: $75 \%$; dotted line: $90 \%$ )

Despite the high productivity in summer, this area experiences relatively low pelagic longline fishing effort in this season, limiting the risk to Tristan albatrosses. Most seabird bycatch in longline fisheries off Uruguay and southern Brazil occurs in winter, and the apparent paucity of Tristan albatrosses in these waters in winter may explain their scarcity in bycatch records from these fisheries (Bugoni et al. 2008, Jimenez et al. 2009). Other fisheries that can impact seabirds, such as demersal longlining and trawling, do not occur in these deep, offshore waters. In winter, when the SW Atlantic is less productive (Wainer et al. 2000), Tristan albatrosses dispersed more widely. Most tracked birds concentrated to the south and west of South Africa in areas associated with the Agulhas and Benguela Currents Stramma \& England 1999), and 2 birds visited sub-Antarctic and Antarctic waters to $\sim 55^{\circ} \mathrm{S}$ during April, May and August.

\section{Overlap with fisheries}

All the non-breeding Tristan albatrosses visited areas of high fishing effort in winter, particularly off southern Africa and in the Indian Ocean. Fortunately, their catch rate in this region appears to be fairly low provided appropriate mitigation measures (e.g. setting only between nautical dusk and dawn, mandatory use of bird scaring lines, etc.). Petersen et al. (2009) recorded only 3 Tristan albatrosses killed, $0.3 \%$ of birds returned to port by fishery observers in the South African large pelagic longline fishery between 1998 and 2005. And since 2005, no further mortalities of this species have been recorded in this fishery. Until recently, appropriate mitigation has not been required in high seas fisheries in this region, but the ICCAT and IOTC will soon require vessels operating south of $25^{\circ} \mathrm{S}$ to use 2 mitigation measures for all longline sets, from a choice of 3 possible measures: bird scaring lines, night setting, or line weighting (ICCAT 2011, IOTC 2012). The Commission for the Conservation of Southern Bluefin Tuna requires vessels catching southern bluefin tuna Thunnus maccoyi to use the conservation measures of the relevant ocean in which they operate. Thus, Tristan albatrosses will be afforded some protection from longline bycatch across their longitudinal range, but only south of $25^{\circ} \mathrm{S}$.

Two Tristan albatrosses (14\% of tracked birds) spent approximately 4 mo off the coast of Namibia, north of $25^{\circ} \mathrm{S}$, where neither the ICCAT nor the government of Namibia require any measures to reduce seabird bycatch in tuna longline operations. This suggests that an appreciable proportion of nonbreeding Tristan albatrosses remain at risk from pelagic longline fishing off Namibia. Seabird bycatch 
on pelagic longliners occurs in these waters (Anderson et al. 2011), so it is imperative that the ICCAT and the government of Namibia afford protection for this Critically Endangered species by extending the area of application of the ICCAT conservation measure (Recommendation 11-09). Our results suggest that current ICCAT seabird conservation measures should be extended north from 25 to $15^{\circ} \mathrm{S}$ in the area from $0^{\circ} \mathrm{E}$ to the Namibian coast. This would also benefit other species susceptible to mortality in longline fisheries in the region, including spectacled Procellaria conspicillata and white-chinned $P$. aequinoctialis petrels, and Atlantic yellow-nosed Thalassarche chlororhynchos and shy/white-capped $T$. cauta/steadi albatrosses (Camphuysen \& van der Meer 2000).

Acknowledgements. Andrea Angel, Marie-Helene Burle, John Cooper and Johnny Wilson assisted with deployment and retrieval of devices. Phil Taylor of BirdLife International kindly supplied cleaned and vetted longline fishing effort data from the ICCAT area of competence.

\section{LITERATURE CITED}

Aarts G, MacKenzie M, McConnell B, Fedak M, Mathiopoulus J (2008) Estimating space-use and habitat preference from telemetry data. Ecography 31:140-160

Anderson ORJ, Small CJ, Croxall JP, Dunn EK, Sullivan BJ, Yates O, Black A (2011) Global seabird bycatch in longline fisheries. Endang Species Res 14:91-106

Baker GB, Wanless RM (2010) Level 1 Risk Assessment of Indian Ocean seabirds susceptible to bycatch in longline fishing operations. IOTC-2010-WPEB-24, presented to the 6th session of the Indian Ocean Tuna Commission's Working Party on Ecosystems and Bycatch, 27-30 October 2010. IOTC, Victoria, Seychelles

BirdLife International (2004) Tracking ocean wanderers: the global distribution of albatrosses and petrels. In: Results from the Global Procellariiform Tracking Workshop, 1-5 September 2003. BirdLife International, Cambridge

BirdLife International (2012) Threatened birds of the world. Available at: www.birdlife.org

Bolker BM (2008) Ecological models and data in R. Princeton University Press, Princeton, NJ

Bugoni L, Mancini PL, Monteiro DS, Nascimento L, Neves T (2008) Seabird bycatch in the Brazilian pelagic longline fishery and a review of capture rates in the southwestern Atlantic Ocean. Endang Species Res 5:137-147

Campagna C, Piolo AR, Marin MR, Lewis M, Fernandez T (2006) Southern elephant seal trajectories, fronts and eddies in the Brazil/Malvinas Confluence. Deep-Sea Res I 53:1907-1924

Camphuysen CJ, van der Meer J (2000) Notes on the distribution of the spectacled petrel Procellaria conspicillata in the South Atlantic Ocean. Atlantic Seabirds 2:13-18

> Croxall JP, Butchart SHM, Lascelles B, Stattersfield AJ, Sullivan B, Symes A, Taylor P (2012) Seabird conservation status, threats and priority actions: a global assessment.
Bird Conserv Int 22:1-34

Cuthbert RJ, Phillips RA, Ryan PG (2003) Separating Tristan albatrosses and wandering albatrosses using morphometric measurements. Waterbirds 26:338-344

Cuthbert RJ, Hilton G, Ryan PG, Tuck G (2005) At-sea distribution of the Tristan albatross Diomedea dabbenena and potential interactions with pelagic longline fishing in the South Atlantic Ocean. Biol Conserv 121:345-355

Dias MP, Granadeiro JP, Phillips RA, Alonso H, Catry P (2011) Breaking the routine: individual Cory's shearwaters shift winter destinations between hemispheres and across ocean basins. Proc R Soc Lond B 278:1786-1793

Finkelstein ME, Doak DF, Nakagawa M, Sievert PR, Klavitter J (2010) Assessment of demographic risk factors and management priorities: impacts on juveniles substantially affect population viability of a long-lived seabird. Anim Conserv 13:148-156

Guilford T, Meade J, Willis J, Phillips RA and others (2009) Migration and stopover in a small pelagic seabird, the manx shearwater Puffinus puffinus: insights from machine learning. Proc R Soc Lond B 276:1215-1223

> Hedd A, Montevecchi WA, Otley H, Phillips RA, Fifield DA (2012) Trans-equatorial migration and habitat use of sooty shearwaters Puffinus griseus from the South Atlantic during the nonbreeding season. Mar Ecol Prog Ser 449: $277-290$

ICCAT (International Commission for the Conservation of Atlantic Tunas) (2011) Supplemental recommendation by ICCAT on reducing incidental bycatch of seabirds in ICCAT longline fisheries. Recommendations adopted at the 2011 Commission meeting, ICCAT. Circular 5058/ 2011, ICCAT, Madrid

> Imber MJ (1992) Cephalopods eaten by wandering albatrosses (Diomedea exulans L.) breeding at six circumpolar localities. J R Soc N Z 22:243-263

IOTC (Indian Ocean Tuna Commission) (2012) Report of the 16th session of the Indian Ocean Tuna Commission. 22-26 April 2012. IOTC-2012-S16-R[E], Victoria, Seychelles

> Jimenez S, Domingo A, Brazeiro A (2009) Seabird bycatch in the southwest Atlantic: interaction with the Uruguayan pelagic longline fishery. Polar Biol 32:187-196

> McConnell BJ, Chambers C, Fedak MA (1992) Foraging ecology of southern elephant seals in relation to the bathymetry and productivity of the Southern Ocean. Antarct Sci 4:393-398

Moors PJ, Atkinson IAE (1984) Predation on seabirds by introduced animals and factors affecting its severity. In: Croxall JP, Evans PGH, Schreiber RW (eds) Status and conservation of the world's seabirds. Tech Publ No. 2, International Council for Bird Preservation, Cambridge, p 667-690

Nel DC, Ryan PG, Nel JL, Klages NTW, Wilson RP, Robertson G, Tuck GN (2002) Foraging interactions between wandering albatrosses Diomedea exulans breeding on Marion Island and long-line fisheries in the southern Indian Ocean. Ibis 144:E141-E154

> Olmos F (1997) Seabirds attending bottom long-line fishing off southeastern Brazil. Ibis 139:685-691

> Passos C, Navarro J, Giudici A, González-Solís J (2010) Effects of extra mass on the pelagic behavior of a seabird. Auk 127:100-107

> Petersen SL, Honig MB, Ryan PG, Underhill LG (2009) Seabird bycatch in the pelagic longline fishery off southern Africa. Afr J Mar Sci 31:191-204 
Phillips RA, Xavier JC, Croxall JP (2003) Effects of satellite transmitters on albatrosses and petrels. Auk 120:1082-1090

Phillips RA, Silk JRD, Croxall JP, Afanasyev V, Briggs DR (2004) Accuracy of geolocation estimates for flying seabirds. Mar Ecol Prog Ser 266:265-272

Phillips RA, Silk JRD, Croxall JP, Afanasyev V, Bennett VJ (2005) Summer distribution and migration of nonbreeding albatrosses: individual consistencies and implications for conservation. Ecology 86:2386-2396

Phillips RA, Silk JRD, Croxall JP, Afanasyev V (2006) Yearround distribution of white-chinned petrels from South Georgia: relationships with oceanography and fisheries. Biol Conserv 129:336-347

Prince PA, Wood AG, Barton T, Croxall JP (1992) Satellite tracking of wandering albatrosses (Diomedea exulans) in the South Atlantic. Antarct Sci 4:31-36

R Development Core Team (2012) R: a language and environment for statistical computing. R Foundation for Statistical Computing, Vienna. Available at: www.rproject.org/

Ryan PG (2007) A field guide to the animals and plants of Tristan da Cunha and Gough Island. Pisces Publications, Newbury

Stramma L, England M (1999) On the water masses and mean circulation of the South Atlantic Ocean. J Geophys Res 104:20863-20883, doi:10.1029/1999JC900139

Tancell C, Phillips RA, Xavier JC, Tarling GA, Sutherland WJ (2013) Comparison of methods for determining key marine areas from tracking data. Mar Biol 160:15-26

Tuck GN, Polacheck T, Bulman CM (2003) Spatio-temporal trends of longline fishing effort in the Southern Ocean and implications for seabird bycatch. Biol Conserv 114: $1-27$

Editorial responsibility: Rory Wilson, Swansea, UK
Tuck GN, Phillips RA, Small C, Thomson RB and others (2011) An assessment of seabird-fishery interactions in the Atlantic Ocean. ICES J Mar Sci 68:1628-1637

Wainer I, Gent P, Goni G (2000) Annual cycle of the BrazilMalvinas confluence region in the National Center for Atmospheric Research Climate Science Model. J Geophys Res 105:26167-26177, doi:10.1029/1999JC000134

Wakefield ED, Phillips RA, Trathan PN, Arata J and others (2011) Habitat preference, accessibility, and competition limit the global distribution of the black-browed albatross. Ecol Monogr 81:141-167

> Wanless RM, Angel A, Cuthbert RJ, Hilton GM, Ryan PG (2007) Can predation by invasive mice drive seabird extinctions? Biol Lett 3:241-244

> Wanless RM, Ryan PG, Altwegg R, Angel A, Cooper J, Cuthbert R, Hilton GM (2009) From both sides: dire demographic consequences of carnivorous mice and longlining for the Critically Endangered Tristan albatrosses on Gough Island. Biol Conserv 142:1710-1718

Weimerskirch H, Salamolard M, Sarrazin F, Jouventin P (1993) Foraging strategies of wandering albatrosses through the breeding season: a study using satellite telemetry. Auk 110:325-342

Weimerskirch H, Louzao M, de Grissac S, Delord K (2012) Changes in wind pattern alter albatross distribution and life-history traits. Science 335:211-214

Wisz MS, Guisan A (2009) Do pseudo-absence strategies influence species distribution models and their predictions? An information-theoretic approach based on simulated data. BMC Ecol 9:1-16

Žydelis R, Wallace BP, Gilman EL, Werner TB (2009) Conservation of marine megafauna through minimization of fisheries bycatch. Conserv Biol 23:608-616

Submitted: April 9, 2013; Accepted: July 4, 2013

Proofs received from author(s): October 16, 2013 